\title{
A Study of Longfellow and Akuwuwu's Native American Writing from Comparative Perspective
}

\author{
HE Yue, LU Jie* \\ Foreign Language College, Chengdu University of Information Technology, China
}

Received May 11, 2020; Revised June 24, 2020; Accepted August 10, 2020

\section{Cite This Paper in the following Citation Styles}

(a): [1] HE Yue, LU Jie, "A Study of Longfellow and Akuwuwu's Native American Writing from Comparative Perspective," Linguistics and Literature Studies, Vol. 8, No. 5, pp. 238 - 246, 2020. DOI: 10.13189/lls.2020.080502.

(b): HE Yue, LU Jie (2020). A Study of Longfellow and Akuwuwu's Native American Writing from Comparative Perspective. Linguistics and Literature Studies, 8(5), 238 - 246. DOI: 10.13189/lls.2020.080502.

Copyright $\bigcirc 2020$ by authors, all rights reserved. Authors agree that this article remains permanently open access under the terms of the Creative Commons Attribution License 4.0 International License

\begin{abstract}
Although American poet Henry Wadsworth Longfellow and Chinese Yi ethnic poet Akuwuwu are in different eras and cultural backgrounds, both of them express deep humanistic care for Native American culture in the Song of Hiawatha and Coyote Traces. This paper firstly discusses some shared views on the Native American by the two poets, such as religious beliefs, planting culture and handicraft. Besides those similarities, this paper also elaborates some differences embodied in their poems, such as the characterization of typical Native American individual and their different understandings of Native Americans' attitudes towards foreign culture. Through a comparative study of the similarities and differences of the Native American writings by the two poets, this paper finds that Longfellow, given his times, looked at American Indians from a WASP perspective, whereas Akuwuwu, given his ethnic minority background, observed American Indians from an ethnic minority's perspective. By analysis of the reasons for their similar and different Native American writings, this paper advocates the exchanges of heterogeneous cultures based on a world cultural consciousness from an objective and equal attitude.
\end{abstract}

Keywords Native American Writing, The Song of Hiawatha, Coyote Traces, Comparative Perspective

\section{Introduction}

The Song of Hiawatha is a national epic written by
American poet Henry Wadsworth Longfellow. The content of the epic is a narration of the history and culture of the Native American. And the purpose of it is to reconstruct the origins of Native Americans through the description of the birth of the national hero Hiawatha and his brilliant achievements for America. Therefore Longfellow created this masterpiece to express his praise and deep sympathy for Native Americans. Coyote Traces records Chinese Yi poet Akuwuwu's poetic sojourn in America. Hence Akuwuwu mainly wrote about the history and living conditions of Native Americans in North America, especially recorded what Native American civilization had experienced from a cross-cultural perspective. This thesis explores the similarities and differences of Native American images shaped by the two poets through a comparative perspective.

\section{Similarities of the Native American Images between Longfellow and Akuwuwu}

Henry Wadsworth Longfellow wrote The song of Hiawatha on the basis of the Finnish national epic Kalevala and his own imagination aroused by Greek and Roman myths and the Bible, while Akuwuwu's Coyote Traces is based on ethnic fieldwork of Native American' life and his own experience as a member of ethnic minority in China. Although their writing materials and inspirations are different, the two poets' descriptions of Native American images still have quite a few similarities. 


\subsection{Religious Faith}

Religious consciousness exists as an ideology in all ancient and contemporary societies. At the same time, religious beliefs of a nation generally have created gods and relied on them, supplemented by totems, sacrifice activities, etc. to guide people to awe and unite the public. So in this paragraph, the religious beliefs of the Native Americans will be revealed by a description of their deities and their religious rituals.

The Native Americans believe in animism and worship nature. Animism is the earliest religious concept among primitive religions which holds that everything has a soul; even animals, plants, mountains and rivers also have souls. Natural objects have no life, but they have souls and have impact on human activities. Native Americans are America's oldest residents but they don't form a unified nation and live dispersedly across the American continent, because they are at war all year round. Affected by various factors such as geographical environment and natural conditions, many tribal groups of different languages, customs and cultures have gradually been formed naturally among Native American; but without exception they worship nature and regard everything in nature as God. The moon, wind, snake, crow, feather, and so on are deified in Henry Wadsworth Longfellow's The Song of Hiawatha. For example, there are some lines in the chapter of "Hiawatha's Childhood": "Downward through the evening twilight...from the full moon fell Nokomis", "see a star falls...fair Nokomis bore a daughter" (Longfellow, 1981:12). From the above lines, it can be seen that Nokomis, Hiawatha's grandmother is the Goddess of moon and Nokomis's daughter, Hiawatha's mother is described as the Goddess of star. They both are Goddesses and natural things. Virtually, wilderness writing was popular in the United States in the 19th century after the American Revolutionary War (1775-1783) which ignited a strong patriotic enthusiasm among Americans and stimulated the writers at that time to get rid of the European cultural influence on the United States. At that time, American writers believed that they should use the vast, uncultivated wilderness in their country as their literary resources to seek identity in the wilderness and construct the identity of the American nation. Longfellow also said that culture makes him forget that he has a root in nature, and his journey in the wilderness reminds him of this. So in The song of Hiawatha, Longfellow is trying to find the balance between the two identities of nature and society as an individual, that is, looking for the balance of Americans who locate in the American continent, but accepting European social civilization, looking for the identity that truly fits in the United States.

The wolf, snake, crow, and feathers are also deified in Akuwuwu's in Coyote Traces. For example, in "fragment of Lissome Faith", it is said that "only for the promises of the ancestors / only for the dream of flying / firmly believing that bird feathers are ladders / lain down by spirits/stepping upwards / divine ancestors / singing freely between ocean and sky" (Aku, 2015:70). In the above lines, feathers are considered a medium of communication with the gods. It is also reminiscent of Akuwuwu as a believer in the Bimo1 religion of the Yi people, and he also believes in the basic doctrine of animism. While writing the faith of Native Americans, he also reshaped the culture of his own nation. This is one of the reasons why Akuwuwu feels intimate in the Native American culture. This also coincides with the poet's own cultural strategy of the Chinese contemporary minority pioneer poet: betrayal, return, and transcendence. In the dilemma of life and death, fission and leaps are made, and life is reconstructed in a desperate situation. Just like phoenix forged in the fires of adversity. All in all, both the two poets noticed the fact that everything in the world is divine and worthy of admiration from Native Americans.

The Native Americans religious rituals are mainly collective activities. The smoke ritual is a good example to illuminate their religious rituals. In the opening chapter of The Song of Hiawatha, the peace pipe mentioned that the Lord of Life created a pipe near the river and then lit the pipe, and the smoke communicated with the Spirits. In this way, the Lord of Life taught his people to stop fighting. Akuwuwu also described the smoke ritual in Coyote Traces. In the poem of "four sisters", the poet wrote: "Tobacco leaf is their way of conversing with the spirits" (Aku, 2015:28). In the eyes of Native Americans, smoking no longer appears so superficial, but serves as a channel of communication with the gods. Obviously, Longfellow and Akuwuwu's descriptions of the religious rituals of Native Americans are extremely similar.

Both poets' descriptions about the Native Americans' religion are involved with animism and some religious rituals. For Longfellow, the Native American's religion is a unique embodiment of Native culture which can differentiate Americans from Europeans and help to build America's cultural confidence. While for Akuwuwu, the Native American's religion is a cultural bond between the Native Americans and Chinese Yi people which can consolidate the affinity between the two races.

\subsection{Farming Culture}

The Native Americans' achievements in agriculture have made extremely significant contributions to the world. When Native Americans explored in the North America, they cultivated many kinds of agricultural crops. The natives have cultivated nearly 100 plants, and they are the pioneers of the North American agriculture. Today, the crops left by Native Americans account for about 4/7 of all crops in the United States. Therefore, in the works by the two poets, there are many descriptions of the agricultural cultivation of Native Americans.

Both poets recorded Native Americans' cultivation of 
crops such as corn and tobacco in their poems. Especially in The song of Hiawatha, the poet specifically used the whole chapter "Hiawatha's fasting" to describe it. Hiawatha had fasted for seven days and seven nights, thinking how to benefit the people, and in the fourth day the Mondamin (the corn God) appeared and Hiawatha fought with the corn god in the last three days of his fast and finally defeated and buried the corn god which became corn later. This chapter reflects Longfellow's wild writing structure of a puritan that one will face some challenges in the wild and should take active actions to overcome it. In the Coyote Traces, poet Akuwuwu also described Native Americans' cultivation of crops. In "the four Indian sisters", Akuwuwu wrote: "corn, pumpkin, sunflower, and tobacco like this many thousands of years ago / on the North American land / myriads of living species flourished / rom among them / native ancestors inspired by divine spirits / choose four plants-corn, pumpkin, sunflower and tobacco leaf" (Aku, 2015:28). This poem not only points out that corns could sustain life and be used to raise their descendants but also shows Akuwuwu's admiration to Native Americana' cultivation of crops as a poet from a heterogeneous culture. Both the two poets show to their readers how essential the cultivation of crops is to Native Americans. Regarding crop cultivation, both poets have described corn cultivation, and they both described it at the beginning of the poem, which reflects their recognition of Native Americans as a farm-based civilization and their unanimous confirmation of Native American's contributions to the development of American agriculture.

\subsection{Handicraft}

The Native Americans, as the first people to live in the American continent, developed their handicraft industry as well as their agriculture. They make handicrafts by using everything that they can get from nature. They use clay, wood, stone and obsidian to make utensils, tools and weapons, and they use metal and feathers to make decorations. Their most characteristic handicrafts are stone carvings, feather jewelry, wood carvings, and leather products. In the fourteenth chapter of The Song of Hiawatha, "Hiawatha's wedding feast" is described as follow: "all bowls were made of basswood / white and polished very smoothly / all the spoons of horn of bison/black and polished very smoothly" (Longfellow, 1981:40). These lines obviously demonstrate Native American's good skills in making bowls and spoons. There are also records about Native Americans' handicraft in Akuwuwu's poems. For example, the most amazing handicraft, the stone axe, is described in "Pipe-Tomahawk" in Coyote Trace: "its one end is a sharp blade / and the other is a delicate pipe / the handle is a special tube for conducting smoke" (Aku, 2015:168). This stone axe made by Native Americans is on one side a sharp axe that can protect people and chop firewood, on the other side a cigarette rod that can be used to relax and communicate with the gods. Actually, this stone axe is a good material evidence to prove the ingenious and exquisite craftsmanship of Native Americans.

It is apparent that both Longfellow and Akuwuwu have a lot of descriptions about Native American's handicraft in poetry. The two poets' descriptions not only highlight the excellent hand-made products of Native Americans, but also the ethnic features of Native Americans' handicrafts. Their vivid descriptions with a tone of compliment actually indicate to some extent the two poets' recognition of Native American civilization.

\subsection{The Reasons for the Similarities in Native American Images}

In the above paragraphs, the similarities in the religious beliefs, farming culture, and handicrafts of the Native Americans described by the two poets have been compared. From a comparative perspective, the two poets' positive attitudes toward Native Americans are evident to be seen.

In Henry Wadsworth Longfellow's poem The Song of Hiawatha and the Chinese Yi poet Akuwuwu' poetry collection Coyote Traces, it can be seen that the poets objectively and fairly described the religion, agriculture, and hand-made products of the Native Americans. There are two major reasons for the similarities of Native Americans' images between the two poets in the above parts: Firstly, the history of any nation is extremely similar in the early stage of its development. For example, human development needs to go through primitive society, and primitive society is inseparable from superstition, religion, stone tools, wood, and so on. Secondly, Longfellow was in the midst of a writing craze for American wilderness, and he was also eager to write about wilderness and Native Americans to seek the identity of America. At the same time, as a member of the Yi people of China's ethnic minorities, Akuwuwu is deeply affected by animistic bimo culture of the Yi people and interested in minority civilization with similar experiences. So, both the two poets' desires to shape the culture of their own nations decide their Utopian imagination upon Native American. Their portrayal of Native Americans' the religious faith, agriculture and handicraft culture mirrors their exploration and appreciation of Native American culture. In their textual world, a rosy picture of Native Americans who have real faith with highly developed agricultural civilization appears intuitively.

\section{Differences of the Native American Images between Longfellow and Akuwuwu}

Although there are some similarities between the two 
poets' descriptions of Native Americans in their poems, the differences of Native American images are also distinctive. Seeking the similarities and probing the differences are two common methodologies used in comparative literature study. The former is to arouse the empathy among people with different culture backgrounds, while the latter is to bridge different cultures and reduce or even eliminate cultural shocks. Therefore, both similarities and differences are worthy of exploration from a comparative perspective. The Song of Hiawatha was created by the American poet Henry Wadsworth Longfellow during the romantic period. It depicts the imagination of the early Native Americans in the course of the colonization. Therefore, Longfellow's poetry expresses the poetic and artistic taste and the marvelous history, culture and customs of Native Americans with a strong romantic style. But because romanticism puts too much emphasis on exaggeration and imagination, the poem shows obvious personal tendency and thus rings unreal. So in Longfellow's works, the prejudice towards other races that furthers the supremacy of European civilization and marginalizes Native Americans is also conspicuous. This supremacy of European civilization was what Longfellow tended to but failed to get rid of. As Longfellow acknowledged himself, the Finnish epic inspired him to write The song of Hiawatha. Longfellow consciously used comparative literature under the impetus of world literary consciousness to build upon his own creation. This shows Longfellow's keen international feeling and insight on the commonalities and differences of national literatures. So Longfellow's works are actually a complex mixture of what to jettison and what to cling on to. Nevertheless, Akuwuwu is a Chinese Yi people in contemporary China under the situation that the Han culture is the Chinese mainstream culture and the $\mathrm{Yi}$ culture has been on the fringe for a long time with few voices of their own. In this case, Akuwuwu traveled to the United States and visited Native Americans who have similar experiences. So Akuwuwu's collection of poems mainly explores the relationship and differences between the Yi culture and Native Americans' culture relating to aboriginal identity, ethnicity and religion, etc., and compares the current status of various ethnic groups in the United States with the Yi people. In this way, Akuwuwu tried to learn about different cultures in the way of literary anthropology to explore how the weak culture rejuvenates in the process of self-criticism. Because of Longfellow and Akuwuwu's different cultural backgrounds and writing purposes, they chose different typical individual characters as representatives for Native Americans and showed to the readers Native Americans' different attitudes towards foreign cultures.

\subsection{Individual Characters as Representatives of Native American}

In both The Song of Hiawatha and Coyote Traces, the themes are conveyed in the poems of legendary Native American leaders. The descriptions of the protagonists take up considerable parts which are worthy of attention. Therefore, in this chapter, the typical characters of Native Americans in both poems will be analyzed by taking Hiawatha and Coyote as representatives.

\subsubsection{Hiawatha in Longfellow's Works}

In Henry Wadsworth Longfellow's poem, Hiawatha is the legendary leader of the Native Americans. Hiawatha had excellent skills in shooting, hunting, and being a gladiator. He was sent by the gods to bring civilization to the Native American tribes. He was endowed the characters of smart, witty, courageous, fearless and righteous, so he could overcome many hardships, to end the melee of Native American tribes and lead the people to live a peaceful life. He taught his people agriculture, navigation, medicine and art, and used his powerful magic to conquer all natural and supernatural enemies. What's more, he eliminated the disease by teaching his people to use herbs, he taught them what medicine could relieve poisons, and how to treat all their illnesses to live longer. He taught the people the skills of planting corn and preventing pests. He also created hieroglyphics, the mystery of drawing and painting, and taught his men to draw pictures. All in all, he is almost an Almighty god depicted in The Song of Hiawatha. But in the last chapter of the poem, in order to highlight the role of the white colonists, before the arrival of the white, Hiawatha felt helpless in the face of hunger and fever, and even lost the courage and confidence to overcome difficulties. He became weak and incapable, even Hiawatha's wife passed away under hunger and fever and so finally he had no choice but to count on the white. In a word, Hiawatha's image shaped by Longfellow is inconsistent and contradictory. For example: "In The Famine", Longfellow wrote: "Oh the famine and the fever / Oh the wasting of the famine! / Oh the blasting of the fever" and "Forth into the empty forest / rushed the maddened Hiawatha / in his heart was deadly sorrow / in his face a stony firmness" (Longfellow, 1981:74). Between lines it can be felt that famine and fever appeared in Hiawatha's land and he was so afraid about the famine and fever. At the same time, it also indicates that maybe Hiawatha can't tackle the problem. But in "Picture-Writing", The poet wrote: "songs of war and songs of hunting / songs of medicine and of magic / all were written in these figures / for each figure had its meaning" (Longfellow, 1981:76). These lines show that Hiawatha foreknew so much about everything. So the descriptions in these two parts are contradictory. Obviously Hiawatha taught everyone magic and medicine and showed great power in face of other Native American tribes and natural disasters, but in the face of famine and fever, contrary to the tenacious and courageous attitude, he did not take any measures to solve the problem, but waited for 
the white people to come and rescue them. Subsequently, in Henry Wadsworth Longfellow's writing, Native Americans were portrayed as exotic, mysterious, noble "savage" images. They were sometimes painted with bright colors and feathers sometimes darkly and solemnly blessing for the corn field and in the prologue of the poetry, the poet firmly stated that: "if you have reverence for God and fortune / then in even savage and want to touch God's right hand in that darkness / and are lifted up and strengthened" (Longfellow, 1981:4). This represents that Hiawatha is just an exotic wild man even though with great power and their people are waiting for the Christian God instead of their own Gods to rescue them.

So in fact, it can be more clearly seen here that this work is not only about the history of Native Americans, but also Longfellow's journey to the wilderness as an American Puritan. Longfellow uses the Puritan model of wilderness writing, that is, the wilderness symbolizes God's test of the selected. Those who set foot on the new continent have to meet challenges, overcome difficulties, domesticate the wilderness and build their homes. Therefore, the image of Hiawatha was more internalized into the poet's own root-seeking consciousness, national consciousness, and historical consciousness, and internalized into the process of American national self-identification and construction. And Hiawatha's survival in the wilderness is a reflection of the American national spirit of tenacity, optimism, and indomitableness. In this way, Longfellow constructed the heterogeneous culture, that is, the Native American culture, rationalized the cultural assimilation by means of myths and metaphors, thereby achieving the effect of heterogeneous cultural assimilation.

\subsubsection{Coyote in Akuwuwu's Works}

In Akuwuwu's poems, Coyote's image is depicted vividly with details. Coyote is a wolf with super powers which reconcile with the religion of animism. He is full of wisdom, intensely courageous, kind, compassionate, but sometimes mischievous. He created all things and Native American civilization. He taught people how to survive and reproduce, and protected his own people when in danger. But in the end, he felt that humans were ferocious and evil and so he abandoned them, which is completely different from Hiawatha's decision. For example, in the poem "Coyote", he is described in this way: "he let the mouthless race in the village grow mouths / express love / taught women to be pregnant with offspring / He has done such things as romancing stars and making two female frogs lose their genitalia" (Aku, 2015:102). From these lines, it can be seen that Coyote is almost immortal. He is extremely creative, cherubic, but a bit annoying. Such characters make Coyote a touch of humanity and seemingly approachable. And in the following description it actually can be found that Coyote is shaped to be a "round" character: he loves and hates; he lives and dies; he expresses human morality and conscience.

But the next two poems display a completely different image of Coyote from that of Hiawatha. In "Future River", Akuwuwu wrote: "was it Coyote / the sprit / that let the "Future River" bears them / such an optimistic outlook/or perhaps the immense sufferings they experienced / let their generous spirit re-bloom / in the depths of their life" (Aku, 2015:96). Akuwuwu discovers that it is Coyote who taught Native Americans to be optimistic in face of mishaps. In "Salmon", Akuwuwu wrote: "it is magic Coyote / in search of permanent place for the Wishram / who turned himself into a drowning baby / he magically aroused the pity of the Willow Woman...from then on / you won freedom and at the Columbia River / a suffering people was born"(Aku, 2015:98). Akuwuwu reveals Coyote's thought that a nation can survive and prosper in a disadvantaged situation and prosperity may be a trip and possibly leads a nation to danger. In these poems, it can be seen that Coyote's image is more philosophical than Hiawatha. Coyote is actually a Native American deity. He has provided the people with what they need, but he has also caused the people to suffer. Coyote's image embodies a possibility of transformation in some degree and he even represents a kind of hope that an ethnical minority can bring to the world civilization. As it was written at the end of "Salmon", Native Americans, the sleeping people, started to wake up and regained freedom after being plundered. This is indeed a hint to Native Americans: sometimes destruction is possible to lead a new life, and this depends on whether one can accept the blow and take the initiative to change himself. Actually, after Akuwuwu and the translator's intentions to connect Native American culture and Chinese Yi culture, the Coyote Traces and another poem collection Tiger Traces written by Akuwuwu form an intertext: both use "trace" as the core word, and the modifiers are the wolf, the legend in Native America and the tiger god of Yi people in China respectively. So it should be noticed that even though the poet writes ethnography of other cultures with extreme restraint and a scientific and objective attitude, because of the poet's backgrounds, his understanding of other cultures is likely to be a mirror of local cultural reflection or the poet tries to learn the Native American culture to explore the development of his own culture.

\subsection{Attitude toward Foreign Cultures}

In the description of the two poets, another significant difference is in Native American's attitude toward foreign cultures. And it has something to do with different identities of the two poets, and the backgrounds of their times. It is not difficult to envisage the miserable experience brought to Native Americans by white colonists: conflict, war, and killing. But the reality of history in Henry Wadsworth Longfellow's poetry has been completely tampered with and obscured. The White became the 
messengers of God instead of invaders. Native Americans did not hesitate to accept their leadership actively. They immediately accepted the gospel and converted to Christianity and completely forsook their own beliefs and culture as if they lost their core of nationality. But in Akuwuwu's poetry, it is completely different. Represented by Native Americans, although most American minorities are actively integrating into the mainstream American culture, they still retain their own characteristics. According to Akuwuwu's poetic expressions, Native Americans have been too severely persecuted by foreigners before, so although they are willing to accept foreign cultures, they become extremely prudent in the acceptance of foreign cultures.

\subsubsection{Native American's Assimilation of Other Cultures in Longfellow's Works}

Facing the advent of "sacred" European civilization and the advent of national doom, Hiawatha, a former national hero, with contradictory mentality, became a tool for the poet's endorsement and tamely embarked on the ideal ending set by the poet for him. In the final chapter "The Departure of Hiawatha", he departed with the purple mist of evening, emerged as an immortal and joined his father's land which is the region of the home-wind the northwest-wind towards death and the carefree afterlife: "Go to the island of blessed / to the kingdom of Ponemah!'(Longfellow, 1981:83). But even before leaving, Hiawatha did not forget to teach the people to convert to the sublime Christianity brought by the sacred white people, "listen to their words of wisdom / listen to the truth they tell you / for the master of life has dent them from the land if light and morning" (Longfellow, 1981:82). It can be clearly seen from the lines that white people have become the replacement of Hiawatha and the imparters of God's will. It is very consistent with the reconstruction of the American culture of the poet as the Puritans, Christ salvation, but is completely contrary to the history of Native Americans.

In "The Departure of Hiawatha", it is recorded like this: "and the white people's coming made the earth has never been so blossoming / the sun has never been so bright" (Longfellow, 1981:80). Confronted with the white's "invasion", Native Americans didn't take any antagonistic actions toward them and just followed the White's instructions. The national hero Hiawatha listened to the great words of the "Almighty God" and was ready to greet these white strangers, cheer them as their brothers and friends in "White Footprints". "When they arrived / it was a happy scene with dancing and singing / Hiawatha said: our peaceful cities are waiting for you / every family is open to you ..." (Longfellow, 1981:79). The arrival of the white colonists as "VIPs" was welcomed by "the whole nation". Hiawatha welcomed the white people as brothers and felt grateful for their coming.

In the penultimate chapter, Longfellow also conceived that white brought industrial civilization and boosted the development of Native Americans. "Diligent, hardworking" white colonists have nothing to do with the "falling apart" of the Native Americans to "the same room to exhaust their vitality". And even the majority of Native American people comply with the white colonists immediately after being dispersed.

From these descriptions, it can be seen that the identity of Native Americans gradually decreases after accepting white leadership and white religion. And actually it can also be safely concluded that assimilation of other cultures without thinking or discerning will eventually lead to the demise of the original culture. The reasons for the contradiction between the posterior and the previous parts in Longfellow's works are as follows: Firstly, Longfellow failed to get rid of the influence of European mainstream culture especially about religion. Secondly, the essence of Longfellow's wilderness writing is to seek America's culture roots, and to redesign American literature. Therefore, Longfellow brought the image of Hiawatha into Americans' self-exploration. Thirdly, Longfellow's works, as one of the most favorite poetry of the American public at that time, was read mainly by America's White Anglo-Protestants (WASP), so Hiawatha's transformation is deliberately made by the poet to meet the ideal readers' horizon of expectation.

\subsubsection{Native American's Dissimilation of Other Cultures in Akuwuwu's Works}

Compared with the description about Native American's attitudes toward foreign culture in Longfellow's works, Akuwuwu's description is quite different. The Native Americans in Akuwuwu's works are blending with foreign culture, which means they consciously integrate into mainstream culture, but still stick to the traditional culture and carry forward the national cultural spirit. For example, in this short poem "the prayer of chief joseph", Akuwuwu wrote: "the land within the fence posts in the homeland of Indians / The whites can only occupy the land outside......never tolerate others to tread upon it!" (Aku, 2015:152). In the second half of the poem, Chief Joseph gave an impassioned speech on the white people's brutal killing of Native Americans and their dark reign, exposing the white people's tremendous damage to Native Americans to ask for their rights and interests. But at the same time what cannot be ignored is that the Native American leader's name was given by the missionary which means Native Americans accept the American tradition. Native American actually is a part of American culture with its own dignity. And it is evident that while Native Americans stick to their culture and maintain their own cultural uniqueness, they actively learn about other cultures and actively absorb other people into their own culture. For example, in the poem of "Dancing Moon", after Akuwuwu spoke about Yi culture in a lecture, 
"Dancing Moon", a lady of Native American Folk Art Festival, had a meaningful conversation with Akuwuwu. For another example, in the poem of "Wolf Skin", at the Native American Folk Art Festival, a white man in Native American wore wolf skin and danced reverently around a sacred drum. It can be seen that Native Americans are displaying the uniqueness of their own culture through festivals, and while integrating with other cultures, they also allow more people to learn about Native American culture. But in the same time, in the poem "Secret Funeral": Akuwuw recorded: "On a snowy afternoon in spring / a full-blooded American Indian in the town of St. Paul, Minnesota / firmly refused to answer my questions about their funeral rituals today" (Aku, 2015:82). In this poem, it can be seen that after a tough experience with foreign cultures, the Native Americans feel slightly indisposed to contact different cultures.

In general, in Akuwuwu's works, it can be seen that the Native Americans' attitude towards heterogeneous cultures is to seek harmony in diversity. They have a cautious attitude towards other cultures but still actively integrate into them. However, they are not being assimilated, but using other cultures as a platform to better promote the uniqueness of their own national culture and communicate with other cultures, thereby promoting the rejuvenation of their own culture. And there are two explanations for the attitude of Native Americans towards foreign cultures embodied in Akuwuwu's poems. The first explanation is that the paradoxical attitude is a relatively objective description of Native Americans' real feeling about foreign cultures, since they experienced very complicate process of dissimilation and assimilation. The second explanation is that Akuwuwu, as an outsider of both Native American and America's White Anglo-Protestants' cultures and a representative for Chinese Yi people, he stands at the height of world culture and tries to explore a way for the ethnic minorities to promote their cultural position in the world.

\subsection{The Reasons for the Differences in Native American Images}

In Henry Wadsworth Longfellow's poem The Song of Hiawatha, the Native American's representative image is exceedingly contradictory. For example, Hiawatha was omnipotent, but he was defeated by fever and famine. Native Americans originally had a god they believed in, but later they converted to Christian God. Native Americans accepted foreign cultures without hesitation, and eventually their own culture ended with demise. These flaws in this work are exactly in line with the poet's own world view and the white people's value orientation at that time. The poet's own wilderness writing journey of seeking roots, seeking the needs of his own national cultural construction after the American Revolution, the poet's own constraints of the times prevented him from objectively describing American indigenous culture. The song of Hiawatha demonstrates that assimilation without distinction will lead to the loss of one's own cultural identity.

In Chinese Yi poet Akuwuwu' poetry collection Coyote Traces, the portrayal of Coyote's image is very speculative and more like the incarnation of Native American culture. Coyote can bring prosperity and may also bring disaster to the nation. He also means a possibility of change, that is, as the Chinese saying goes: "misfortune might be a blessing in disguises". Coyote also carries an image of doubt, representing the poet's doubts and concerns about where the Native Americans will ultimately go. The description of the Native Americans' attitude of seeking common ground while shelving differences in foreign cultures in the Coyote Traces actually reflects the poet's thinking about how ethnic minorities survive in a multi-cultural world. In the multicultural era; it is of far-reaching significance to try to defend the common humanistic spiritual values of Chinese and American people.

The reasons why Native Americans have different attitudes toward foreign cultures written by the two poets are as follows. Firstly, based on different eras and different cultures, two poets bring their self-awareness into their writings. After American War of Independence, America was a new continent with a large number of creative materials for aggressive foreign settlers like Longfellow. As a puritan, Longfellow indiscriminately accepted the world culture dominated by European culture and influenced by the ideology of white supremacy. So Longfellow was conscious of acceptance of other national cultures, but he trended to white supremacy and Christian missions without doubt. Akuwuwu is in a contemporary globalized and diversified world system. The prosperity and development of world culture has the characteristics of co-existence and co-prosperity of different cultures. Akuwuwu has received the influence of China's mainstream Han culture and the declining culture of the Yi ethnic minority. Inspired by the great unity of national integration of the Chinese government, Akuwuwu has, as a descendant of ethnic minorities, a sense of urgency for the transformation of his own ethnical culture, anxiety about the decline of his own ethnical culture, and hesitation to integrate into the mainstream culture and fear of assimilation by the mainstream culture. So in Akuwuwu's works, Coyote has the characteristics of unknown and changing and Native Americans' attitude toward foreign cultures is quite prudent. Secondly, their purposes of writing are different. The purpose of Longfellow is to create a national epic of Native Americans, to speak for minorities, to use Native Americans as a creative material for his own wilderness writing process, and to pursue his own cultural identity, reconstruct American culture. Hence Longfellow's works show his nod toward 
self-reconstructing American identity, while Akuwuwu's purpose is to grasp the deep thoughts of the Native Americans as a culturally disadvantaged group as Chinese ethnic minority, and also to communicate with his own ethnic groups in the cultural process and historical evolution. Therefore, Akuwuwu's works mainly provide readers with a kind of thinking on where the minority culture will go and a kind of cultural Renaissance expectation beyond the nation. Thirdly, their writing styles are different. Longfellow's writing is deeply influenced by romanticism, so Longfellow's writing may downplay or even distort historical facts in some degree. But Akuwuwu is more of a poetic documentary writing which reflects the reality of what he saw, heard, and thought, so the description of the image of Native Americans is more objective. Fourthly, the two poets' cultural identities are different. In Longfellow's poems, it can actually be seen that the poet clarified his American identity by distorting and degrading Native Americans. However, Akuwuwu's return to the Yi people's tradition is through getting involved with a heterogeneous culture and even embodying a certain degree of transcendent cultural identity, that is, the poet adopts an objective attitude and borrows national culture as a literary expression to express universal thinking beyond national culture. It is precisely under the guidance of poets' cultural identities that the way they communicate with heterogeneous cultures has been changed, thus externalizing their different depictions of Native American images.

\section{Conclusions}

Longfellow, given his times, looked at American Indians from a WASP perspective, whereas Akuwuwu, given his ethnic minority background, observed American Indians from an ethnic minority's perspective. The comparative study of Native American writings by the two poets cast lights on some basic principles about cultural exchanges in the present multi-cultural world. Through comparing the two poets' similar and different descriptions of Native Americans, it can be seen that the exchange of heterogeneous cultures should be based on a world cultural consciousness through the establishment of heterogeneous cultural bonds. World cultural consciousness encourages people to understand other cultures, and the construction of heterogeneous cultural connections makes cultural exchange possible. The exchange of heterogeneous cultures should also be based on an objective and equal attitude as much as possible, otherwise this is not a cultural exchange, but a distortion of other cultures, a cultural hegemony and cultural bullying.

\section{Notes}

1 The Bimo is a unique cultural phenomenon of the Yi ethnic minority in China. In the Yi language, "Bi" refers to chanting scriptures, and "Mo" refers to messengers and communicators. "Bimo" in Yi language refers to a special messenger who communicates with gods by chanting scriptures.

\section{Acknowledgments}

This essay is an achievement of the project "Study of Akuwuwu's Poetic Sojourn in America from the Perspective of Comparative Literature" (YZWH1918) funded by the Sichuan Yi Culture Study Center and "Ideological and Political Education in English and American Literature Courses" (BKJX2019073) supported by Chengdu University of Information Technology.

\section{REFERENCES}

[1] Akuwuwu. Selection of Akuwuwu's Poems. Chengdu: Sichuan nationalities publishing house 2004.

[2] Akuwuwu. Coyote Traces: Akuwuwu's Poetic Sojourn in America. Trans. Wen Peihong and Mark Bender, Beijing: Nationalities Publishing House, 2015.

[3] Bender, Mark\& Huang Li. Southwest Ethnic Literature of China in English- speaking World-An Interview with Professor Mark Bender of Ohio University, USA. Journal of Ethnology, 25(2014): 52-56+117-118.

[4] Calhoun, Charles C. Henry Wadsworth Longfellow: A Rediscovered Life. Boston: Beacon, 2004.

[5] Han, Jing. The song of Hiawatha: a Hymn to the Indians. Movie Review. 2006(5):90-92.

[6] Irmscher, Christoph. Henry Wadsworth Longfellow redux[M]. Illinois: University of Illinois, 2006.

[7] Jin, Wen, and Liu Daxian. Double writing: Aku Wuwu and Epistemology of Chinese Writing in the Americas. Amerasia Journal: 2012 (2): 45-63

[8] Meng, Hua. Imagology in Literature Comparatives. Beijing: Peking University Press, 2001.

[9] Longfellow, Henry Wadsworth. The song of Hiawatha. Trans. Wang Keyi. Shanghai: Shanghai Translation Publishing House, 1981.

[10] Liu, Qitao \& Wang Kun. On the Original Ecological Aesthetic Spirit of Contemporary Chinese Yi Poetry in Daliang Mountain. Chinese Journal of Literary Criticism. 2017(4):78-87.

[11] Parini, Lay \& Brett C. Millier, The Columbia History of American Poetry. Cambridge: Columbia University, 2005.

[12] Schoolcraft, Henry R. The Myth of Hiawatha and Other Oral Legends: Mythologic and Allegoric of the North American Indians. Philadelphia: J.B. Lippincott \& Co; London: Trubner \& Co, 1856. 
[13] Wen,Peihong. Poetry as an International Language: A Study on American Indian Civilization in Akuwuwu's Poetry. Journal of Southeast Minzhu University, 2008 (S2): 48-52, 232.

[14] Xie, Youshun. What is Poetry about. Beijing: China Social Sciences Press, 2001.
[15] Zhang, Yanping. The song of Hiawatha and the Construction of American National Literature. Wuhan University, 2015.

[16] Zhou, Yunfang. The Expression of Indian Culture in Yi Nationality Poet Akuwuwu's Collection of Poems. Journal of Qiannan Normal University for Nationalities 2016(1):48-51,60. 